\title{
Administrators in higher education: organizational expansion in a transforming institution
}

\author{
Roxana-Diana Baltaru ${ }^{1}$ - Yasemin Nuhoḡlu Soysal ${ }^{1}$
}

Published online: 10 November 2017

(C) The Author(s) 2017. This article is an open access publication

\begin{abstract}
Recent European research has revealed growth in the number of administrators and professionals across different sections of universities - a long established trend in US universities. We build on this research by investigating the factors associated with variation in the proportion of administrators across 761 Higher Education Institutions (HEIs) in 11 European countries. We argue that the enactment of expanded and diversified missions of HE is one of the main factors nurturing universities' profesional and administrative bodies. Our findings support such an assertion; regardless of geographical and institutional differences, HEIs with high levels of "entrepreneurialism" (e.g. in service provision and external engagement) are characterized by a larger proportion of administrative staff. However, we find no empirical support for arguments citing structural pressures and demands on HEIs due to higher student enrolments, budget cuts or deregulation as engines driving such change. Instead, our results point towards, as argued by neo-institutionalists, the diffusion of formal organization as a model of institutional identity and purpose, which is especially prevalent at high levels of external connectedness.
\end{abstract}

Keywords Higher education P Professional and administrative staff - Organizational expansion · Functionalism $\cdot$ Neo-institutionalism $\cdot$ Entrepreneurialism

The last couple of decades have marked a shift in the very nature of higher education (HE) as a knowledge institution. The early nineteenth century Humboldtian model of an elite institution prioritizing the pursuit of knowledge on its own left its place to the late twentieth century myth of the knowledge society (Meyer et al. 2006). Higher education institutions (HEIs) are facing

Baltaru acknowledges funding from the Council of Social and Economic Research (ES/J500045/1) and Soysal acknowledges funding from the British Academy (SG152470).

Roxana-Diana Baltaru

rdbalt@essex.ac.uk

Yasemin Nuhoḡlu Soysal

soysal@essex.ac.uk

1 Department of Sociology, University of Essex, Wivenhoe Park, Colchester, Essex CO43SQ, UK 
an "age of supercomplexity" in which knowledge claims are no longer made solely by universities, but knowledge production is increasingly built in private firms and nonacademic organizations (Barnett 2000). Such a context has fostered expanded and diversified HEI missions, whereby they are expected to proactively engage with wider society and explicitly articulate their contribution to social and economic development (Ramirez and Tiplic 2014). This in turn also affects the ways in which HEIs are run. At the governance level, this shift in HEIs' orientation anticipates institutional and financial autonomy as a precondition (Maassen 1997; Christensen 2011). At the organizational level, it has been associated with an increase in the number of administrators, along with declining influence and autonomy for academics (Ginsberg 2011).

A growing literature considers how administrative growth leads to changes in academic identities and propels professionalism and managerialism into the higher education sphere (Gumport and Sporn 1999; Amaral et al. 2003; Whitchurch 2004; Henkel 2005; Deem et al. 2007; Krücken et al. 2013; Kehm and Teichler 2013). However, there is little empirical investigation of the determinants of change in the academic and administrative composition of university staff. We ask: Which factors boost the number of administrators in HEIs? Using a sample of 761 HEIs in 11 European countries, we bring to the fore empirical evidence which suggests that the differences in the number of administrators across HEIs can be accounted for by the enactment of formal organization as a model of institutional identity and purpose.

\section{Universities' professional and administrative bodies}

Scholars often study changes in the governance of HEIs by investigating the variations in the number of academic and professional/administrative staff or the distribution of expenditure between these two sections of university staff (for reviews of the literature, see Leslie and Rhoades 1995; Schneijderberg and Merkator 2013). Despite the general assumption that the academic body represents the core component of HEIs, since the mid-twentieth century administrative resourcing has been rivaling and, at times, outpacing that of academics. This has been a clear trend in the US (Hansen and Guidugli 1990; Gumport and Pusser 1995). No aggregate analysis exists at the European level. However, similar developments in European countries have also been documented (Rhoades and Sporn 2002). Perhaps the most striking case is the UK. Higher Education Statistics Agency (HESA) data shows that in the 2000s the number of managers increased almost twice as fast as the number of academics, meaning the overall proportion of professional and administrative staff already exceeded that of academic staff (Grove 2012, see also Universities UK 2013).

Where data is available in greater detail, variations can be observed across administrative categories. In Germany, the increase in administrative staff in the 1990s/ early 2000s was due to growth in the higher-grade positions and newly created higher education professions (Blümel et al 2010; Kehm et al 2010; Krücken 2011; Krücken et al 2013). Similarly, in Norway the number of managers and administrative officers overtook the number of clerical positions starting in 1991. Although positions of higher administrative staff grew by $215 \%$ between 1987 and 1999 , there was also a $28 \%$ decrease in the positions of clerical staff (Gornitzka and Larsen 2004). In Finland, between 1987 and 1992, the number of administrators grew by 39\%, while that of lowskilled service staff fell by 11.8\% (Blümel et al. 2010, see also Visakorpi 1996). These studies suggest that the increase in administrative staff reflects a rise in the number of professional and highly qualified administrative staff, and that this rise is at the expense of technical and administrative staff with lower levels of qualifications. 


\section{The administrative university as an organizational actor: Searching for explanations}

Policy reforms in Europe and beyond have converged on projecting the idea of a HE that is less elitist and more inclusive, less inward-looking and more oriented to the needs of the outside world. This expanded and societally integrated model of higher education has been widely promoted by international institutions such as UNESCO, the OECD and various nongovernmental organizations, as well as incorporated into the EU's policy agenda (Commission of the European Communities 2006). HEIs are expected to pursue these goals by becoming less state dependent and more autonomous in their institutional and financial affairs (de Boer and File 2009; Estermann and Nokkala 2009; Maassen and Stensaker 2010; Enders et al. 2013). European universities increasingly assimilate standardized goals and an active and "entrepreneurial" orientation towards achieving them in an efficient and systematic manner (Clark 1998). Krücken (2011) describes this process as a transformation of European universities, historically located between the state and academic professions, from their distinct traditional structures into "organizational actors". An organizational actor is defined as "an integrated, goal-oriented entity that is deliberately choosing its own actions and that can thus be held responsible for what it does" (Krücken 2011, p. 4; see Meyer 2009 for a more extended discussion on modern actorhood).

From an organizational actorhood perspective, the strengthening of the entrepreneurial identity means that universities are increasingly goal oriented (consider the widespread adoption of mission statements) and increasingly focused on technical effectiveness and accountability (consider the standardization of strategic action plans). They also articulate an entrepreneurial identity through proactive engagement with a variety of stakeholders, from industry to non-governmental organizations (e.g. trusts and foundations) and supranational actors (e.g. EU Directorate-General Education and Culture). Equipped with this vision of inclusive and integrated higher education, HEIs consciously organize themselves in order to accommodate a growing body of students as well as societal demands, thus expanding their mission. New positions and organizational units that have emerged on university rosters in the last 20 years are indicative of the university's new purpose and identity: planning, marketing, student services, student placement, quality control, external relations, regional development, knowledge and technology transfer in addition to research and enterprise (Marginson and Considine 2000; Krücken et al. 2013). We suggest that the increase in the number of administrators across European HEIs is a by-product of organizational expansion in this sense. To analyze European HEIs' transformation into organizational actors, we follow a two-prong strategy. First, we test the "functionality" of universities' organizational expansion by assessing whether its effects on administrative growth can be explained by structural pressures. Second, we assess the role of the external environment in accounting for universities' administrative growth as a model of institutional identity and purpose.

\section{Administrative expansion: Efficiency or legitimacy?}

The widespread organizational transformation of HEIs is often considered to be a response to structural pressures and needs. From such a view, a strengthened administrative core is needed for the management of an institution run in a neo-liberal climate, i.e. divorced from state regulation and funding. In the pursuit of the HE modernization agenda, European governments have indeed introduced a certain degree of re-regulation towards deregulation and 
decentralization, with the aim of giving HEIs more freedom in institutional and financial matters (Neave and van Vught 1991; Christensen 2011). Clark (1998: 5) suggests that such a move creates an organizational challenge for European HEIs, which traditionally lack "selfsteering," "deepening the need for a greater managerial capacity" and a stronger administrative body. In addition, as European universities' close integration with ministries of education and research is relaxed, they need to be responsive and accountable to external stakeholders, thus producing pressure on internal governance (Christensen 2011). The New Public Management thesis further suggests that changes in the organizational makeup of HEIs mirror managerial practices in the private sector, due to these practices offering "efficient solutions" (Tolofari 2005).

From a neo-institutionalist perspective, on the other hand, it is precisely such functional beliefs (e.g. that a managerial administrative body is necessary and efficient for deregulated steering) that can transform a model of action into performance - in other words, the enactment of a model to conform to the expected. A formidable body of literature originating from sociological institutionalism draws attention to the global cultural context that grounds and sustains an "organizational revolution," whereby strategic action and rationalization have developed as golden standards (Drori et al. 2009; Meyer and Bromley 2013). This explains the spectacular diffusion of formal organization after World War $\mathrm{II}^{1}$ and the consequent expansion of administrative apparatus: "organizational forms expand in arenas with complex technical and political goals or interests but also in social areas where goals are unclear, interdependencies low and causal texture obscure" (Meyer and Bromley 2013:2, see also Brunsson and Sahlin-Andersson 2000; DiMaggio and Powell 1991). The possibility emerges that, in the case of higher education, the proliferation of administrative units and positions is not simply the result of internal structural requirements but part of universities' pursuit of acting in legitimate ways through their links to an external environment which itself is highly organized and hosts models and logics of purposive and strategic actions.

\section{Hypotheses}

The emergent analytical challenge is that both functionalist (structural needs) and neoinstitutionalist (external legitimacy) perspectives would predict that the organizational expansion of HEIs is positively associated with an increase in the number of administrators. As has already been noted, it is not always easy to empirically differentiate the two lines of argument, as "at times, an institutional lens complements, rather than competes with functional views of education policy and administration" (Bromley 2016). This is particularly the case in crosssectional analysis, where causality is difficult to establish. Much neo-institutionalist research indeed builds on longitudinal data and analysis, where causal impact of the wider environment can be tested. In the absence of such Europe-wide data on HE staff, we attempt to investigate the nature of the relationship between organizational expansion and the proportion of

\footnotetext{
${ }^{1}$ Neo-institutionalist theory traces the contemporary organizational revolution back to World War II and its aftermath, a time when skepticism surrounding traditional mechanisms of state control had led to global orientation towards forms of governance rooted in traditional natural law liberalism (Meyer and Bromley 2013). The US, in particular, promoted forms of self-regulation and private governance to be implemented through soft law such as standards, certifications and codes of conduct. The growing authority of scientific principles contributed to the perceived universal applicability of rationalized action. Thus, formal organization became a major expectation at all social levels (Drori et al. 2003).
} 
administrators in HEIs across Europe by developing a number of hypotheses to address, directly and also by implication, structural needs and external legitimacy arguments.

Our starting point is that HEIs engaged in organizational expansion tend to have a higher proportion of administrative staff than those not involved in such expansion. The European Tertary Education Register (ETER) that we use in this research allows for the operationalization of organizational expansion from the perspective of horizontal differentiation (e.g. multiple campuses to provide higher education to local people in areas not sufficiently served) and service provision (e.g. elementary educational facilities and modern support services). A HEI may be characterized as having high levels of organizational expansion if it exhibits horizontal differentiation and consequently provides a large array of services. We hypothesize:

$\boldsymbol{H} 1$ The proportion of administrators is larger in multi-sited HEIs.

$\boldsymbol{H} 2$ The proportion of administrators is larger in HEIs with a higher proportion of expenditure on goods and services (other than staff).

The relationship between organizational expansion and proliferation of the administrative infrastructure is typically perceived as a functional one, and explained by internal structural pressures. Expanding student numbers would put pressure on direct operational needs and effective management (Gibb et al. 2012). The increasing shortage of core funding (e.g. government grants), particularly in the face of a de-regulated HE sector, should further exacerbate such pressures (Tolofari 2005). As HEIs can no longer rely on state funding, they may develop organizational subdivisions to enhance their ability to compete for alternative funding sources (e.g. fundraising and development offices, public relations, student recruitment etc.), consequently boosting the number of professionals and administrators. It follows that the relationship between organizational expansion and the proportion of administrators might merely be an artifact of changes like increase in student numbers and shortage of funding.

H3 The proportion of administrators is larger in HEIs with a higher number of students. $\boldsymbol{H} 4$ The proportion of administrators is higher at lower levels of core funding.

From a neo-institutionalist view, however, the relationship is not straightforward, as the association may also signal HEI's enactment of an organizational model to proactively pursue diversified missions and student profiles regardless of their internal needs. Thus, the relationship between organizational expansion and the proportion of administrators would be independent of enrolment numbers and availability of funding. By implication, we hypothesize the potential effects of organizational expansion as the following:

H3A The positive relationship between organizational expansion and the proportion of administrators holds when controlling for student numbers.

H4A The positive relationship between organizational expansion and the proportion of administrators holds when controlling for level of core funding.

We develop two further hypotheses in order to test external legitimacy arguments directly. The neo-institutionalist perspective views outward-orientation and proactive engagement as part of HEIs proving themselves to be strategic and rational actors. Furthermore, neoinstitutionalist studies have documented the crucial role that third parties (e.g. governmental 
and non-governmental organizations and supranational bodies) play in the diffusion of formal organization principles and practices that have currency in the wider environment and thus provide legitimacy (see Ramirez and Christensen 2013; Meyer and Bromley 2013). Accordingly, we expect HEIs that are closely connected with the wider environment (e.g. through national and international funding agencies) to be frontrunners in responding to organizational expansion with an enlarged administrative body.

H5 The proportion of administrators is larger in HEIs with a higher proportion of third party funding.

The relevance of the founding institutional setting to organizational practices has been argued in organizations theory (Stinchcombe 1965) and frequently included in neo-institutionalist analyses (Oertell and Söll 2016; Ramirez and Christensen 2013). In the European context, the Bologna declaration in 1999 marked the institutionalization of the vision of a rationalized higher education landscape and the codification of entrepreneurial HE organizational logic at transnational governance levels (Keeling 2006). ${ }^{2}$ From a neo-institutionalist perspective, universities founded in such densely institutionalized environments should be more predisposed to taking for granted and adopting the organizational concepts and models afforded and legitimated by such environments. To encapsulate this argument, we hypothesize:

H6 The proportion of administrators is larger in HEIs founded after the 1999 Bologna Declaration.

On the other hand, New Public Management inspired arguments emphasize that the current changes in HEIs are symptomatic of a managerial model borrowed from the private sector (Pollitt and Bouckaert 2004; Tolofari 2005). Deregulation of higher education opens up channels for closer connections with the private sector and it follows that HEIs directly linked to it (rather than those in the state sector) would be more likely to assimilate the sector's organizational expertise and practices.

$\boldsymbol{H} 7$ HEIs that are run privately have a larger proportion of administrators compared with those which are publicly run.

Additionally, we consider the impact of two institutional characteristics with regards to profile: whether the HEI has university status and prestige (the rank of the HEI). Considering the traditional centrality of universities in the public discourse surrounding higher education, it is possible that they (rather than other HEIs which do not have university status) would be the first targets expected to comply with emergent organizational models. Quantitative performance measures such as prestige rankings, are argued to influence organizational behavior in $\mathrm{HE}$, as well as other institutional domains such as healthcare and nonprofits (Sauder and Espeland 2009; Bromley and Meyer 2014).

\footnotetext{
${ }^{2}$ The Bologna Declaration refers to the Joint Declaration of the European Ministries of Education convened in Bologna, on the 19th of June 1999. It aims at the harmonizing of European HE systems (e.g. adoption of comparable degrees and cycles) and the furthering of proactive and productive engagement with each other by means of comparable structures and outputs. See https://www.eurashe.eu/library/modernisingphe/Bologna_1999_Bologna-Declaration.pdf. (accessed 7 June 2017).
} 
Following the functionalist emphasis on individually informed rational choice as the basis for organizational decision making, the relationship between organizational expansion and the number of administrators should be interpreted by institutional level differences. Alternatively, a core neo-institutional argument and research finding is that higher-education systems exhibit increasing isomorphism globally (Drori et al. 2003; Meyer et al. 2006; Ramirez 2013; Bromley 2016). This suggests that the effects of organizational expansion on the proportion of administrators transcend geographical and institutional differences.

$\boldsymbol{H} \boldsymbol{8}$ The positive relationship between organizational expansion and the proportion of administrative staff holds true regardless of country-level and institutional characteristics.

\section{Data and methods}

Secondary data for this project were selected from ETER Project $(2011)^{3}$ for the academic year 2011/2012. The register provides a census of HEIs in Europe, including information on organizational characteristics and educational activities. ${ }^{4}$ However, the raw data are incomplete in respect to countries and variables. ${ }^{5}$ In our analysis we included 761 HEIs from 11 countries across all European regions: Belgium, Cyprus, Germany, Italy, Lithuania, Luxembourg, Norway, Portugal, Sweden, Switzerland and the United Kingdom.

As we aim to provide an explanatory account for differences in the size of the administrative body in HEIs across countries, we use the proportion of administrative staff in total staff as our dependent variable. In line with previous studies in the field, we investigate the number of administrators relative to the number of academics (Bergmann 1991; Gornitzka and Larsen 2004; Blümel et al. 2010). The proportion of administrative staff has been derived by dividing the total number of administrative staff by the total number of staff (academic and administrative, headcounts). ${ }^{6}$ Administrative staff include: academic support staff, management,

\footnotetext{
${ }^{3}$ Data have been provided by the European Tertiary Education Register (ETER), funded by the European Commission under the contract EAC-2013-0308.

${ }^{4}$ As for 2011, ETER data includes 2673 HEIs in 36 countries: the 28 EU member states, EEA-EFTA countries (Iceland, Liechtenstein, Norway and Switzerland) and candidate countries (the Former Yugoslav Republic of Macedonia, Montenegro, Serbia and Turkey). Data were collected on institutions offering courses at at least level 5 according to the ISCED-2011 classification of educational degrees. Public research organizations were excluded, as well as institutions which provide tertiary education as a side activity. Institutions below the threshold of 200 students and 30 full-time staff were also excluded with the exception of HEIs granting degrees at the doctoral level or equivalent (ISCED 8). Hence, the register includes almost all HEIs that provide bachelors, masters and doctorate degrees, according to the International Standards Classification of Education (ISCED 2011).

${ }^{5}$ The number of HEIs in this study was determined by two-stage consideration, namely the original country level non-response and the subsequent variable non-response. Several countries did not provide data: Hungary, Montenegro, Romania, Serbia, Slovenia, Slovakia and Turkey. Furthermore, we included only those countries for which information was available across all the variables selected for the current analysis. Outliers, with unrealistic values which required further investigation, have been eliminated, based on consultations with ETER representatives.

${ }^{6}$ We opted to use headcounts as the measure for number of staff, instead of equivalent full-time staff for two reasons: a) in ETER data not all countries have returned the number of full-time administrative staff (e.g. UK, Italy), the choice of which would imply significant reductions in the sample size and b) from an analytical perspective, focusing on headcounts enables us to capture growth in all staff having administrative functions, which is particularly important in the current labor market which is characterized by wide diversity of modes of employment.
} 
quality control and administration as well as maintenance and operational staff. We acknowledge the unavailability of breakdowns as a limitation to providing a more in-depth picture of how different professional and administrative categories in HE respond to organizational expansion. Sub-categories of administrative staff may be differently affected by cultural and socio-economic environments (Schneijderberg and Merkator 2013). Nevertheless, focusing on administrative staff as a whole represents a first step in cross-national European HE research, where comparable data are yet to be achieved.

The level of organizational expansion is operationalized by whether the HEI is horizontally diversified and by investment in goods and services. Multi-sited, capturing horizontal differentiation, is a binary variable where " 1 " indicates that the HEI has other establishments at the local, sub-regional level (NUTS3). ${ }^{7}$ The proportion of expenditure on goods and services in total expenditure covers current expenditure (other than on staff) on educational resources such as teaching and learning materials, contracted and purchased services (e.g. support services, ancillary services, management of school facilities), as well as property taxes where applicable (Lepori et al 2015, elaborated in UOE 2013).

Regarding structural pressures, the number of students is measured as an interval variable formed by summing up students at every level of higher education: ISCED 5 (short cycle tertiary education), ISCED 6 (bachelor or equivalent), ISCED 7 and ISCED 7 long degree (masters or equivalent) and ISCED 8 (doctoral or equivalent). This indicator was log transformed to address positive skew. Universities' core funding is represented by the proportion of funding that can be freely used for the operations of the whole institution. This includes sources such as government base grants (at the national or regional level), interest on endowments, donations at the institutional level and income from premises. $^{8}$

We measure external connectedness by the proportion of third party funding in total revenues, which includes grants from national and international funding agencies for research activities (e.g. national research councils, European Union framework programs and international programs such as Eureka), funds from charities and non-profit organizations (e.g. Wellcome Trust, Bill Gates foundation), as well as income from educational activities such as contracted research. Furthermore, we operationalize the external environment by foundation era, i.e. whether the HEI was founded before ("0") or after ("1") the Bologna Declaration of 1999.

HEI governance shows whether the institution is publicly or privately run: "ultimate control (...) with reference to who has the power to determine the general policies and activities of the institution and to appoint the officers managing the school (...) also extend to the decision to open and close the institution" (Lepori et al 2015: 31). Publicly controlled HEIs will have received no less than half of their funds from the government. The original ordinal variable representing private, privategovernment dependent and public institutions was transformed into a binary indicator comparing private and semi-private HEIs ("1") with public ones ("0"). For this, and other indicators mentioned above, the sample has been complemented with data from

\footnotetext{
${ }^{7}$ NUTS3 is the Nomenclature of Territorial Units for Statistics referring to sub-regions, e.g. arrondissements (Belgium), administrative regions (Czech Republic), districts (Germany), counties (Sweden) etc.

${ }^{8}$ We have identified a number of HEIs in Germany that report values of " 0 " as their core budget. Upon consultation with ETER representatives, we learned that the National Statistical Authorities have confirmed these to be applicable to a number of private HEIs.
} 
the Higher Education Statistics Agency (HESA) in order to address the item nonresponse in the case of the UK. ${ }^{9}$

HEI institutional characteristics are controlled for status, i.e. whether the HEI has university status (coded " 1 " and " 0 " otherwise), and rank, i.e. whether the HEI is among the top 400 ranked HEIs in Europe published by Times Higher Education for the year 2011 (coded "1" and " 0 " otherwise). ${ }^{10}$

Table 1 reports the descriptive statistics for all the variables in the study.

A regression-based model is used to assess the relationship between the proportion of administrators and the substantive predictors. In our dataset, HEIs are grouped by countries, hence observations are likely to be more similar within clusters (Intraclass Correlation Coefficient $=.16$ ). In order to address this issue we used a fixed-effects model which controls for any unobserved differences between countries, thus providing more accurate estimates than ordinary least square regression ( $\mathrm{F}$ Test $=7.31, p<.001$ ). The fixed-effects model also allows us to look at cross country differences in order to address the neo-institutionalist argument that the effect of organizational expansion on the proportion of administrators holds true at a crossnational level.

ETER was conceived as a census, and thus the number of HEIs differs substantially from one country to another, partly reflecting the differences in student populations across European states. We acknowledge this limitation and as a result do not attempt to estimate country level effects, but merely control for them in order to identify factors that may affect the number of administrators in HEIs at the institutional level, regardless of the national context. Working with an aggregate dataset of

Table 1 Descriptive statistics

\begin{tabular}{lllll}
\hline Interval variables & Mean & Standard deviation & Min & Max \\
Prop. administrators (headcounts) & .33 & .13 & .03 & .88 \\
Prop. goods \& services (Euros) & .30 & .11 & .05 & .98 \\
Students (ISCED 5,6,7,8) & 11,564 & 16,090 & 64 & 201,270 \\
Prop. core funding (Euros) & .61 & .30 & .00 & 1 \\
Prop. third party funding (Euros) & .11 & .12 & .00 & .73 \\
Binary variables & Number & Percentage of Total & & \\
Multi-sited (in sub-region) & 151 & $20 \%$ & & \\
Post-Bologna founded & 116 & $15 \%$ & & \\
Private and semi-private HEIs & 145 & $19 \%$ & & \\
HEIs with university status & 634 & $83 \%$ & & \\
Top 400 ranked HEI in Europe & 108 & $14 \%$ & & \\
\hline
\end{tabular}

\footnotetext{
${ }^{9}$ Expenditure on goods and services was replaced by the HESA indicator "all other operating expenses" (excluding staff costs). The total number of students was extracted by adding up all undergraduate and postgraduate students (full-person). Core funding was derived from the HESA indicator capturing income from funding body grants (e.g. Higher Education Funding Council for England), endowments and investments. Third party funding has been based on the HESA indicator capturing "income from research grants and contracts," which includes funding from national research councils and charities, as well as supranational organizations (e.g. EU government and bodies), thus converging with the ETER definition. For finances, data were transformed from pounds into Euros at the 2011 exchange rate. All variables were selected for 2011/2012.

${ }^{10}$ We chose Times Higher Education (THE) ranking over other ranking systems, such as Shangai or QS, based on the diversity of criteria THE uses, being both academic (e.g. teaching, research, citations) and also reflective of the changing university environment (e.g. international mix, industry income). As a binary variable differentiating HEIs in the top 400 from lower ranked counterparts, THE correlates strongly with alternative rankings.
} 
Table 2 Population and sample

\begin{tabular}{lll}
\hline Country & HEIs in ETER & Response rate \\
\hline Lithuania & 48 & $77 \%$ \\
Luxemburg & 1 & $100 \%$ \\
Norway & 69 & $15 \%$ \\
Portugal & 137 & $23 \%$ \\
United Kingdom & 170 & $88 \%$ \\
Belgium & 89 & $29 \%$ \\
Switzerland & 35 & $83 \%$ \\
Cyprus & 41 & $7 \%$ \\
Germany & 448 & $80 \%$ \\
Italy & 244 & $32 \%$ \\
Sweden & 51 & $75 \%$ \\
Total & 1333 & $57 \%$ \\
\hline
\end{tabular}

Source: The European Tertiary Education Register (2011)

Note: Response rate refers to the percentage of institutions among a country's total number of HEIs that returned complete data on all variables of interest in the study

European HEIs is also more appropriate for the current study as some countries exhibit institutional level non-response (see Table 2). Accordingly, our results illustrate whether the hypothesized relationships hold true for the average European university in our sample. The Breusch-Pagan/Cook-Weisberg has not detected any issue of heteroscedasticity ( $\chi^{2}=3.23, p>.05$ ). We assumed a linear relationship between the independent variables and the proportion of administrators in total staff. The fixed effects results are reported with robust standard errors. In order to ensure that the results are not affected by outliers, the analysis was alternatively run on a sample excluding HEIs with particularly low or high proportions of administrators by cutting off the top and bottom 5\% of the distribution. The results were consistent in both analyses.

The model, where " $\mathrm{i}$ " represents the HEI level and " $\mathrm{j}$ " represents the country level becomes:

$$
\begin{aligned}
\text { Prop.Admins }_{\mathrm{ij}}= & \left.\beta_{0}+\beta_{1}(\text { Multisited HEI })+\beta_{2} \text { (Prop.Goods\&Services Exp. }\right) \\
& +\beta_{3} \log (\text { Students })+\beta_{4}(\text { Prop. Core Funding }) \\
& +\beta_{5}(\text { Prop. Third Party Funding })+\beta_{6}(\text { Post Bologna Founded }) \\
& +\beta_{7}(\text { Legal Status })+\beta_{8}(\text { University Status })+\beta_{9}(\text { Rank })+\varepsilon_{\mathrm{ij}}
\end{aligned}
$$

\section{Findings and discussion}

Table 3 shows the empirical results. Of the two organizational expansion variables, we see that multi-sited HEIs do not significantly differ from single-sited ones with regard to the proportion of administrators ( $\mathrm{B}=-.022, p>.05$; $\mathrm{H} 1$ disconfirmed), whereas HEIs with higher investments in goods and services are significantly more likely to expand their administrative infrastructure (H2 confirmed). Controlling for institutional level differences, we find that a $1 \%$ percentage increase in the proportion of expenditure spent on goods and services predicts 
Table 3 Fixed effects model predicting the proportion of administrators

\begin{tabular}{ll}
\hline Variables & Model \\
\hline Multi-sited HEI (in sub-region) & -.022 \\
Proportion of goods and services expenditure (Euros) & $(.012)$ \\
Number of students (ISCED 5,6,7,8) & $.198^{* *}$ \\
& $(.041)$ \\
Proportion of core funding (Euros) & .009 \\
& $(.005)$ \\
Proportion of third party funding (Euros) & $.037^{* *}$ \\
Foundation era (post-Bologna founded) & $(.010)$ \\
Governance (private and semi-private HEIs) & $.172^{* * *}$ \\
HEIs with university status & $(.032)$ \\
Rank (top 400 HEIs in Europe) & $.039^{* *}$ \\
F-test & $(.008)$ \\
$\mathrm{N}$ & $-.052^{*}$ \\
$\mathrm{R}^{2}$ (within countries) & $(.018)$ \\
\hline
\end{tabular}

Notes: $* \mathrm{p}<.05, * * \mathrm{p}<.01, * * * \mathrm{p}<.001$

Robust standard errors in the parentheses

Coefficients and robust standard errors rounded at the third decimal

an approximately 20 percentage increase in the proportion of administrators $(\mathrm{B}=.198$, $p<.01)$. We further explore this finding by evaluating the role of structural pressures in this relationship, as well as the role of external legitimacy drives in universities' administrative growth, controlling for structural pressures.

\section{Structural pressures and budget needs}

From a functionalist perspective, this finding can be interpreted in relation to the need to effectively manage larger institutions, as the massification of higher education and increasing budget constraints bring new organizational challenges for service provision and administration (Gornitzka et al. 1998; Tolofari 2005). However, we find that the number of students is not a significant predictor of the proportion of administrative staff $(\mathrm{B}=.009, \mathrm{p}>.05)(\mathrm{H} 3$ disconfirmed $)$, the results clearly show that the relationship between organizational expansion in terms of goods and services and the proportion of administrators is independent of the size of the student body $(\mathrm{H} 3 \mathrm{~A}$ confirmed). Moreover, HEIs with lower levels of core funding are not more predisposed to embrace professional and administrative expansion as a way to effective management. On the contrary, the proportion of administrative staff is positively associated with core funding $(\mathrm{B}=.037, \mathrm{p}<.01)$ ( $\mathrm{H} 4$ disconfirmed). Neither do we find support for the functionalist argument which highlights the borrowing of models from the private sector in an increasingly deregulated and underfunded HE system. Contrary to $\mathrm{H} 7$, we see that on average, the proportion of administrators is 5 
percentage lower in private and semi-private HEIs when compared with public ones $(\mathrm{B}=-.052, p<.05)$. The results up to this point reinforce the importance of furthering our understanding of the changing makeup of HE personnel beyond simple functional need explanations.

\section{External connectedness and the diffusion of formal orgnization}

Our findings support the neo-institutional arguments regarding external connectedness. We can see that, controlling for all other institutional differences, a 1 percentage increase in the proportion of third party funding is associated with an over 17 percentage increase in the proportion of administrators ( $\mathrm{B}=.172, p<.001$; H5 confirmed). This emphasizes the importance of the external environment, where connectedness with external stakeholders can act as a proxy for exposure to the broader cultural frameworks characterizing wider society (Meyer 2009). Given the failure of internal functionalist arguments to satisfactorily account for cross-national patterns of organizational change, there has been a shift towards reconceptualizing the role of environmental factors in an increasingly interconnected world (Meyer 2000; Ramirez 2010, 2013; Ramirez and Christensen 2013). The broader environment, rooted in the ontological centrality of reason and the consequent glorification of rationalized action, exerts "pressure and opportunities for rationalization," through standardization, rankings and accounting (Meyer and Bromley 2013). In the process of proactively engaging with the external environment, HEIs themselves are reconstructed as organizational actors, elaborating their administrative infrastructure. This may explain why, on average, regardless of their diverse structural and cultural backgrounds, HEIs that are externally engaged through third party research funding, display a significantly higher proportion of administrators when compared with those HEIs simply relying on state funds and/or HE fees.

The role of external connectedness is equally important in understanding the diffusion of formal organization at the transnational level, where organizational models that emphasize effectiveness, strategy and accountability are increasingly codified as scientific approaches to social purpose and promoted through elaborate expertise and consulting mechanisms. It can be argued that many of the ongoing European projects within the Bologna process are driving the diffusion of formal organization through standardization of educational purposes and ideals. ${ }^{11}$ Indeed, our findings indicate that European HEIs founded after the Bologna Declaration, compared to those founded before, are more likely to have an expansive administrative infrastructure ( $\mathrm{B}=.039, p<.01 ; \mathrm{H} 6$ confirmed).

The diffusion argument also underlies the neo-institutional observation that the blurring of the boundaries between the public and private sectors is more profound than the simple "borrowing" of management ideals and practices in order to meet the current challenges of higher education (Meyer and Bromley 2013). Given the purported centrality of higher education for global competition and social development, European states themselves have become keen adopters of organizational ideals and relevant models available in the transnational environment, thus driving public HEIs to reorganize themselves as effective organizational actors. This offers the prospect of understanding why the proportion of administrators is

\footnotetext{
${ }^{11}$ Remarkably, Bologna is a voluntary higher education reform process. Originally signed by 29 countries in 1999, it was later opened to members of the Council of Europe. Currently, 49 higher education systems are signatories.
} 
significantly higher in public HEIs than in private and semi-private ones, as we have found in our analysis.

External connectedness on the other hand could mean new pressures and demands on universities that consequently require specialized staff and a stronger administrative infrastructure. It is possible, for example, that HEIs founded in the post-Bologna environment have equipped themselves with a more elaborate administrative infrastructure in order to comply with the formally established demands of harmonization and standardization. As state resources in the post-Bologna era are increasingly uncertain, new HEIs would be expected to be more likely to comply with models in the environment in order to gain acceptance and access to resources. They might be expected for example to satisfy the requirements of their funders by developing "administrative structures and procedures to complement the structures of resource providers" (Gornitzka et al. 1998 p.39; see also Leslie and Rhoades 1995). While such functionalist interpretation is plausible, our findings do not completely support such a position. Expansive administrative and professional structures and procedures develop of their own accord, not because HEIs are necessarily dependent on funders. As we have shown, it is not resource depleted HEIs that engage with and adopt the entrepreneurial and proactive organizational model as reflected in administrative expansion. HEIs founded in the postBologna environment, independent of their resource needs and dependency, are more likely to take for granted and enact such organizational models as a legitimate way of being a "proper" HE actor.

Overall, our findings put into perspective the organizational expansion of HEIs as a model of institutional identity and purpose. In their commitment to further formalization, HEIs' purposive engagement with entrepreneurial activities and supranational programmes contribute to self-perpetuating professionalization and diversification. Our results hold beyond country-level and institutional characteristics (H8 confirmed), giving further credibility to the idea of increasing HE isomorphism.

\section{Reflections on HE organizational transformations and further research directions}

The current paper takes a first step in using European level organizational data in order to address the nature of universities' administrative growth as an empirical question. Our findings point to European HEI's increasingly taken for granted new organizational identity and structure. It is expected that neo-liberal reforms pushed both at national and transational levels put HEIs in a position of vulnerability (Guzmán-Valenzuela and Barnett 2013). Increased student numbers in the face of public budget cuts should then increase the appeal of instrumental and managerial approaches to higher education and implicitly a stronger administrative and professional base to push for organizational survival. However, our results reveal that HEIs expand their administrative body irrespective of their student numbers, and they do so more if they are organizationally resourceful both in terms of core funding and external connections. Moreover, while the model of a university as a proactive, purposeful organization with an expansive administrative and professional spine is not traceable to precarious conditions or private environments, we find it to be embraced widely by the typical European public HEI.

The organizational model underlining HEIs' administrative expansion is closely linked with broader changes in the European higher education landscape. Scholars have pointed out the 
competing logics that the diffusion of this model brings to the fore (Gumport 2000; Olsen 2007; Dobbins et al. 2011; Pinheiro 2016). Not only do European universities face global challenges of supercomplexity in terms of rearticulating their centrality as knowledge institutions (Barnett 2000), but the implementation of an increasingly "managerialized" governance has implications for the ways that academics long assumed how to profess their profession (Ginsberg, 2011; Harris 2011). The extensive literature on HE transformations expresses much concern about the idea of university as a community of scholars with institutional autonomy and individual freedom being eclipsed by the new norm of a growing body of professionals and administrators (Ginsberg 2011). The debate often focuses on whether the "administrative periphery" expands to the detriment of "academic heartlands" (Clark 1998).

While we acknowledge the importance of the debate in its broader context, as a post-hoc hypothesis, we test the relationship by using the number of administrators to predict the number of academic staff, net of institutional differences. Figure 1 illustrates the predicted probabilities. We can see that the the organizational expansion of HEIs presupposes the engagement of both the administrative periphery and the academic core, the number of academic staff being positively associated with the number of administrative staff. Given the widespread adoption of the new HEI identity and organization, it would be useful to assess its implications for universities' knowledge mission, while assessing whether the new model can secure the sustainability of this mission in the face of current challenges. The age of supercomplexity brings a wide variety of challenges, and differentiating among them allows HEIs to better understand the nature of their transformation.

In this paper, we provide a European overview of HE institutional transformations. Our analysis at the European level gives credence to the transnational diffusion argument. We note however that according to our results $24 \%$ of the variation in the proportion of administrators is attributable to national level differences (Table $3, \mathrm{R}^{2}$ between HEIs $=.24$ ). On closer investigation of the dispersion of country level residuals, we find moderate country differences (Fig. 2). In our analysis, we used a fixed effects model in order to identify the institutional level factors that nurture the share of administrative staff net of country level differences. While the fixed-effects model controls for country level differences in administrative staff, it does not allow for assessment of national level characteristics (e.g. levels of deregulation and decentralization of the HE system) and variations in the degree of national HE systems' exposure to the transnational environment (e.g. the implementation of the Bologna process; membership of

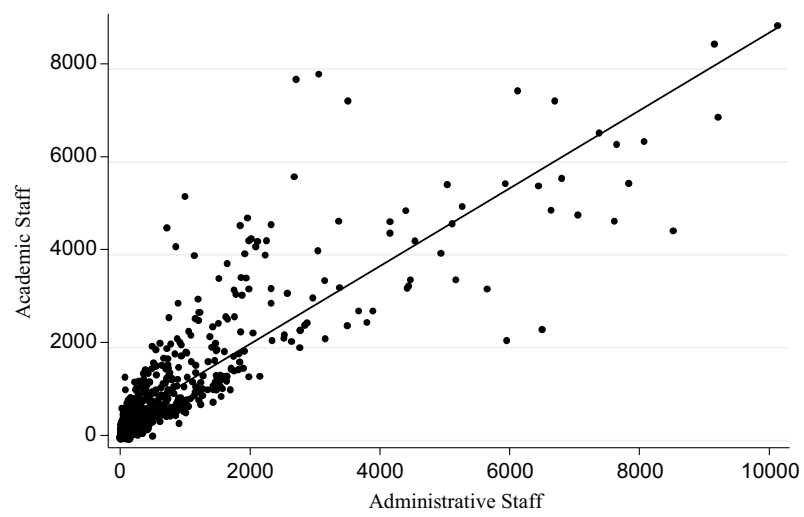

Fig. 1 Number of administrative staff predicting the number of academic staff (2011) 


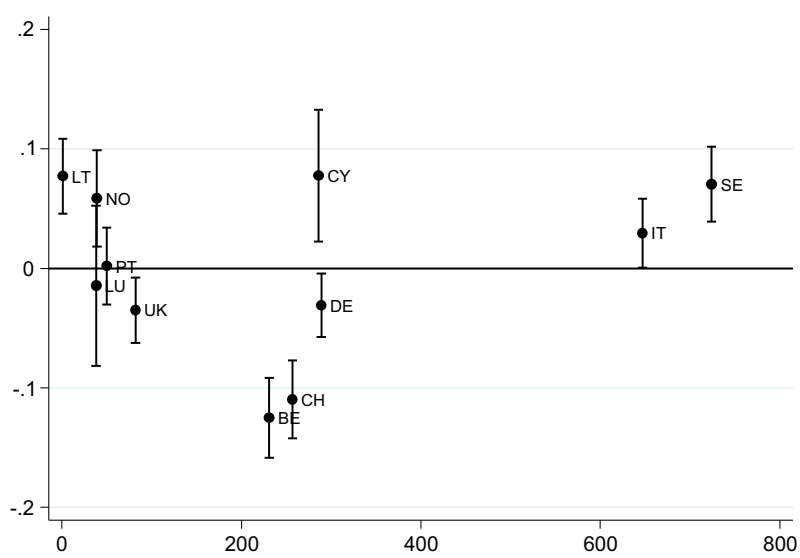

Fig. 2 Countries' positioning with regard to the predicted proportion of administrators for the average European University in the sample

European and international level professional associations) as predictors in order to further explore the nature of national variation. Further research should focus on breaking down country level variation by utilizing national level data and engaging analytical techniques that allow operationalization of between country variation (e.g. random effects models). Further research should also consider other indicators of organizational expansion (e.g. diversification of mission statements and related establishment of new units and offices) in order to capture possible variations in the manifestations of organizational diffusion across HE systems. Such comprehensive data to conduct a European level analysis do not yet exist. Finer grained analyses at the national level may compensate for the absence of detailed data at the European level. As such, the current findings offer the conceptual and empirical basis for further national and transnational level studies to situate the local dynamics and patterns of HE organizational transformations into the global context.

Open Access This article is distributed under the terms of the Creative Commons Attribution 4.0 International License (http://creativecommons.org/licenses/by/4.0/), which permits unrestricted use, distribution, and reproduction in any medium, provided you give appropriate credit to the original author(s) and the source, provide a link to the Creative Commons license, and indicate if changes were made.

\section{References}

Amaral, A., Meek, L. V., \& Larsen, I. M. (Eds.). (2003). The higher education managerial revolution? Dordrecht: Kluwer.

Barnett, R. (2000). University knowledge in an age of supercomplexity. Higher Education, 40(4), 409-422.

Bergmann, B. R. (1991). Bloated administration: Blighted campuses. Academe, 77, 12-16.

Blümel, A., Kloke, K., Krücken, G., \& Netz, N. (2010). Restrukturierung statt Expansion. Entwicklung im Bereich des Nichtwissenschaftlichen Personals an Deutschen Hochschulen. Die Hochschule, 20(2), $154-172$.

Bromley, P. 2016. Policy and administration as culture: Organizational sociology and cross-national education trends. In K. Mundy, A. Green, R. Lingard \& A. Verger (Eds.), The Handbook of Global Policy-making in Education (pp. 470-489). Wiley-Blackwell.

Bromley, P., \& Meyer, J. W. (2014). "They are all organizations": The cultural roots of blurring between the nonprofit, business, and government sectors. Administration and Society, 49(7), 939-966.

Brunsson, N., \& Sahlin-Andersson, K. (2000). Constructing organizations: The example of public sector reform. Organization Studies, 21(4), 721-746. 
Christensen, T. (2011). University governance reforms: Potential problems of more autonomy? Higher Education, 62(4), 503-517.

Clark, R. B. (1998). Creating entrepreneurial universities. Wagon Lane: Emerald Group Publishing Limited.

Commission of the European Communities (2006). Communication from the Commission to the Council and the European parliament- Delivering on the Modernization Agenda for Universities: Education, Research and Innovation. http://ec.europa.eu/euraxess/pdf/COM\%282006\%29_208.pdf. Accessed 27 May 2015.

De Boer, H. \& File, J. (2009). Higher education governance reforms across Europe. The European Centre for Strategic Management of Universities http://www.utwente.nl/bms/cheps/publications/Publications\%202009 /C9HdB101\%20MODERN\%20PROJECT\%20REPORT.pdf. Accessed 27 May 2015.

Deem, R., Hillyard, S., \& Reed, M. (2007). Knowledge, higher education, and the new managerialism: The changing management of UK universities. Oxford: Oxford University Press.

DiMaggio, P. J., \& Powell, W. W. (Eds.). (1991). The new institutionalism in organizational analysis. Chicago, IL: University of Chicago Press.

Dobbins, M., Knill, C., \& Vögtle, E. M. (2011). An analytical framework for the cross-country comparison of higher education governance. Higher Education, 62(5), 665-683.

Drori, G. S., Meyer, J. W., Ramirez, F., \& Schofer, E. (2003). Science in the modern world polity. Institutionalization and globalization. Stanford: Stanford University Press.

Drori, G. S., Meyer, J. W., \& Hwang, H. (2009). Rationalization and Actorhood as dominant scripts. In R. E. Meyer, K. Sahlin, M. J. Ventresca, \& P. Walgenbach (Eds.), Institutions and ideology. Research in the sociology of organizations (vol. 27, pp. 17-43). Bingley: Emerald.

Enders, J., de Boer, H., \& Weyer, E. (2013). Regulatory autonomy and performance: The reform of higher education re-visited. Higher Education, 65(1), 5-23.

ETER Project (2011). The European Tertiary Education Register. http://eter.joanneum.at/imdaseter/. Data received 3 May 2015.

Estermann, T. \& Nokkala, T. (2009). University autonomy in Europe I- exploratory study. EUA Publications: European University Association. http://www.rkrs.si/gradiva/dokumenti/EUA_Autonomy_Report_Final. pdf. Accessed 12 April 2016.

Gibb, A., Haskins, G., Hannon, P. \& Robertson, I. (2012). Leading the Entrepreneurial University. The National Centre for Entrepreneurship in Education (NCEE). http://eureka.sbs.ox.ac.uk/4861/1/EULP___LEADERS PAPER final dec 19.pdf. Accessed 16 May 2016.

Ginsberg, B. (2011). The fall of the faculty: The rise of the all-administrative university and why it matters. Oxford: Oxford University Press.

Gornitzka, A., \& Larsen, I. M. (2004). Towards professionalisation? Restructuring of administrative work force in universities. Higher Education, 47(4), 455-471.

Gornitzka, Å., Kyvik, S., \& Larsen, I. (1998). The bureaucratisation of universities. Minerva, 36(1), 21-47.

Grove, J. (2012). University Manager Numbers Rising 'Twice as Fast as Academics'. Times Higher Education. https://www.timeshighereducation.com/news/university-manager-numbers-rising-twice-asfast-asacademics/419229.article. Accessed 17 June 2016.

Gumport, P. J., \& Pusser, B. (1995). A case of bureaucratic accretion: Context and consequences. The Journal of Higher Education, 66(5), 493-520.

Gumport, P., \& Sporn, B. (1999). Institutional adaptation: Demands for management reform and university administration. In J. Smart (Ed.), Higher education: Handbook of theory and research (pp. 103-146). New York: Agathon Press.

Gumport, P. (2000). Academic restructuring: Organizational change and institutional imperatives. Higher Education, 39(1), 67-91.

Guzmán-Valenzuela, C., \& Barnett, R. (2013). Academic fragilities in a marketised age: The case of Chile. British Journal of Educational Studies, 61(2), 1-18.

Hansen, W. L., \& Guidugli, T. F. (1990). Comparing faculty and employment gains for higher education administrators and faculty members. Journal of Higher Education, 61(2), 142-159.

Harris, D. (2011). Managerialism and myth: The legitimacy of management in higher education and the consequences of its decline. Power and Education, 3(2), 117-127.

Henkel, N. (2005). Academic identity and autonomy in a changing policy environment. Higher Education, 49(1/2), 155-176.

Keeling, R. (2006). The bologna process and the Lisbon research agenda: The European Commission's expanding role in higher education discourse. European Journal of Education, 41(2), 203-223.

Kehm, B. M., Merkator, N., \& Schneijderberg, C. (2010). Hochschulprofessionelle?! Die unbekannten Wesen. ZFHE-Zeitschrift für Hochschulentwicklung, 5(4), 23-39.

Kehm, B.M., \& Teichler, U. (2013). The Academic Profession in Europe: New Tasks and New Challenges. London: Springer. 
Krücken, G. (2011). A European Perspective on New Modes of University Governance and Actorhood. Centre for Studies in Higher Education: Research \& Occasional Paper Series CSHE.17.1. http://files.eric.ed. gov/fulltext/ED529727.pdf. Accessed 1 September 2015.

Krücken, G., Blümel, A., \& Kloke, K. (2013). The managerial turn in higher education? On the interplay of organizational and occupational change in German academia. Minerva, 51(4), 417-442.

Lepori B., Bonaccorsi A., Daraio A., Daraio C., Gunnes H., Hovdhaugen E., Ploder M., Scannapieco M., Wagner-Schuster D. (2015), ETER project. Handbook for Data Collection. Brussels, June 2015.

Leslie, L. L., \& Rhoades, G. (1995). Rising administrative costs. Seeking explanations. The Journal of Higher Education, 66(2), 187-212.

Maassen, P. A. M. (1997). Quality in European higher education: Recent trends and their historical roots. European Journal of Education, 32(2), 111-127.

Maassen, P. A. M., \& Stensaker, B. (2010). The knowledge triangle, European higher education policy logics and policy implications. Higher Education, 61(6), 757-769.

Meyer, J. W. (2000). Globalization: Sources and effects on national states and societies. International Sociology, $15(2), 235-250$.

Meyer, J. W. (2009). Reflections: Institution theory and world society. In G. Krücken \& G. Drori (Eds.), World society. The writing of John W. Meyer (pp. 36-67). Oxford: Oxford University Press.

Meyer, J. W., \& Bromley, P. (2013). The worldwide expansion of organization. Sociological Theory, 31(4), 366-389.

Meyer, J. W., Ramirez, O.F., Frank, J.D. \& Schofer, E. (2006). Higher Education as an Institution. Center of Democracy, Development and The Rule of Law: Stanford. CDRL Working Papers. https:/www.academia. edu/14876375/Higher Education as an Institution. Accessed 17 May 2016.

Marginson, S., \& Considine, M. (2000). The Enterprise University. Melbourne: Cambridge University Press.

Neave, G. \& van Vught, F.A. (1991). Prometheus bound: The changing relationship between government and higher education in Western Europe. Oxford: Pergamon.

Oertell, S., \& Söll, M. (2017). Universities between traditional forces and modern demands: The role of imprinting on missions of German universities. Higher Education, 73(1), 1-18.

Olsen, J. (2007). The institutional dynamics of the European university. In P. Maassen \& J. Olsen (Eds.), University dynamics and European integration (pp. 25-54). Dordrecht, Netherlands: Springer.

Pinheiro, R. (2016). Humboldt meets Schumpeter? Interpreting the "entrepreneurial turn" in European higher education. In S. Slaughter \& B. Taylor (Eds.), Higher education, stratification, and workforce development (pp. 291-310). Cham, Switzerland: Springer.

Pollitt, C., \& Bouckaert, G. (2004). Public management reform: A comparative analysis $-2^{\text {nd }}$ edn. Oxford: Oxford University Press.

Ramirez, O. F. (2010). Accounting for excellence -transforming universities into organizational actors. In L. M. Portnoi, D. V. Rust, \& S. S. Bagley (Eds.), Higher education, policy and the global competition phenomenon (pp. 43-59). Basingstoke: Palgrave MacMillan.

Ramirez, O. F. (2013). World society and the university as formal organization. Journal of Education, 1(1), $124-153$.

Ramirez, O. F., \& Christensen, T. (2013). The formalization of the university: Rules, roots, and routes. Higher Education, 65(6), 695-708.

Ramirez, O. F., \& Tiplic, D. (2014). In pursuit of excellence? Discursive patterns in European higher education research. Higher Education, 67(4), 439-455.

Rhoades, G., \& Sporn, B. (2002). New models of management and shifting modes and costs of production. Europe and the United States. Tertiary Education Management, 8(1), 3-28.

Sauder, M., \& Espeland, W. N. (2009). The discipline of rankings: Tight coupling and organizational change. American Sociological Review, 74(1), 63-82.

Schneijderberg, C., \& Merkator, N. (2013). The new higher education professionals. In B. M. Kehm \& U. Teichler (Eds.), The academic profession in Europe: New tasks and new challenges (pp. 53-93). London: Springer.

Stinchombe, A.L. (1965). Social Structure and Organizations. In J.G. March (Ed.), Handbook of organizations (pp. 142-193). Chicago: Rand McNally \& Co.

Tolofari, S. (2005). New public management and education. Policy Futures in Education, 3(1), 75-98.

Universities UK. (2013). Patterns and trends in UK Higher education- in collaboration with HESA. http://www. universitiesuk.ac.uk/policy-and-analysis/reports/Documents/2013/patterns-and-trends-uk-higher-education2013.pdf. Accessed 23 February 2016.

UOE. (2013). UNESCO OECD EUROSTAT Data Collection on Education Statistics Manual -Volume 1. Montreal, Paris, Louxembrug, June, 2013.

Visakorpi, J. K. (1996). Academic and administrative interface: Application to national circumstances. Higher Education Management and Policy, 8(2), 37-41.

Whitchurch, C. (2004). Administrative managers - a critical think. Higher Education Quarterly, 58(4), $280-298$. 